\title{
A Chemoenzymatic Approach to C1-C6 Fragment of (-)-Putaminoxin
}

\author{
Sandra V. Vassiliades, Graziela G. Bianco, Luiz S. Longo Jr.* \\ Instituto de Ciências Ambientais, Químicas e Farmacêuticas - Univerisdade Federal de São Paulo \\ Rua Prof. Artur Riedel, 275, Diadema, SP, Brazil, CEP 09972-270 \\ *luiz.longo@unifesp.br
}

Keywords: Putaminoxin, decalactones, kinetic enzymatic resolution

\section{INTRODUCTION}

(-)-Putaminoxin (1) is a decalactone isolated from the culture filtrates of the fungus Phoma putaminum, a leaf necrosis agent of the weed Erigeron annuus. $^{1,2}$ These and other structure related compounds showed significant phytotoxic activity against several plants. ${ }^{1,3}$ Herein we describe our efforts to the synthesis of the C1-C6 fragment of the title compound [(S)-5-hydroxyhept-6-enoic acid (2)], using a kinetic enzymatic resolution approach as key step.

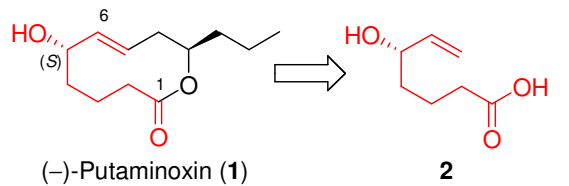

Figure 1. (-)-Putaminoxin (1).

\section{RESULTS AND DISCUSSION}

As previously described, ${ }^{4}$ the racemic allylic alcohol $( \pm)-3$ could be prepared in 3 steps from commercial available 1,5-pentanediol (Scheme 1).

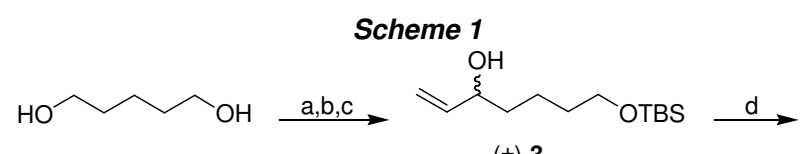

$( \pm)-3$

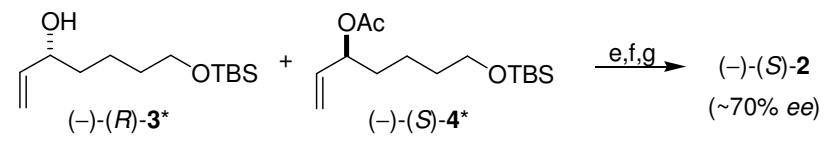

Reagents e conditions: (a) $i: \mathrm{NaH}$, THF, r.t., $45 \mathrm{~min}$; ii: TBSCl, r.t., $45 \mathrm{~min}$ (70\%); (b) 2.5 eq. IBX, tert-butanol, $80{ }^{\circ} \mathrm{C}$, $1 \mathrm{~h}(72 \%)$; (c) $i: \mathrm{CH}_{2}=\mathrm{CHMgBr}$, THF, $0{ }^{\circ} \mathrm{C}, 80 \mathrm{~min}$; ii: $\mathrm{NH}_{4} \mathrm{Cl}$ aq. (72\%); (d) CALB, vinyl acetate, hexanes, $32{ }^{\circ} \mathrm{C}, 15 \mathrm{~h},(-)-(R)-3(e e=98 \%)$ e $(-)-(S)-4$ (ee = 94\%) (best condition; see Table 1); (e) chromatographic separation of $(-)-(S)-4$; (f) TBAF, THF, r.t., 4 h; (g) 0.4 eq. 2-iodobenzoic acid, 2.6 eq Oxone®, $\mathrm{MeCN} / \mathrm{H}_{2} \mathrm{O}(2: 1)$ r.t., $6 \mathrm{~h}$ (yield not optimized). ${ }^{*}$ The absolute configuration of the products were giving based on the enantioselectivity of the enzyme, but it is under investigation.

The kinetic enzymatic resolution of $( \pm)-3$ was performed using the lipases CALB, $P$. cepacia [immobilized on ceramic (Amano PS-CII) and diatomite (Amano PS-DI)] or P. fluorescens (Amano AK) as biocatalysts (Table 1). The time of the KR is a critical point to obtain the products with good ee, probably because the ratio of the reaction is similar to the two enantiomers of 3.

Table 1. Kinetic Resolution (KR) of ( \pm )-3.

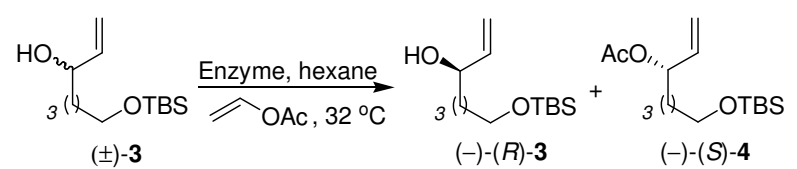

\begin{tabular}{|c|c|c|c|c|}
\hline \multicolumn{2}{|c|}{$( \pm)-3$} & \multicolumn{2}{|c|}{$(-)-(R)-3$} & $(-)-(S)-4$ \\
\hline Entry & Lipase & Time & $\begin{array}{c}(-)-(R)-3 \\
(\% \text { ee })^{\star}\end{array}$ & $\begin{array}{c}(-)-(S)-4 \\
(\% \text { ee })^{*}\end{array}$ \\
\hline $1^{4}$ & $C A I R$ & $24 \mathrm{~h}$ & 99 & 91 \\
\hline 2 & UALD & $15 \mathrm{~h}$ & 98 & 94 \\
\hline 3 & P. cepacia & $20 \mathrm{~h}$ & 97 & 65 \\
\hline 4 & Amano PS CII & $15 \mathrm{~h}$ & 97 & 78 \\
\hline 5 & P. cepacia & $20 \mathrm{~h}$ & $>99$ & 71 \\
\hline 6 & Amano PS-DI & $15 \mathrm{~h}$ & 99 & 79 \\
\hline 7 & $\begin{array}{l}\text { P. cepacia } \\
\text { Amano AK }\end{array}$ & $20 \mathrm{~h}$ & 22 & 27 \\
\hline
\end{tabular}

From the results showed in Table 1 is noteworthy that lower reactional times led to high ee of (-)-4. Reaction of $( \pm)-3$ with CALB using dimethylcarbonate (DMC), DMC/hexanes and MeCN as solvents led, in all cases, to recovery of starting material. The acetate (-)-4 was deprotected by TBAF and the alcohol thus obtained was oxidated by catalytic IBX affording the acid (-)-2 in $70 \%$ ee.

\section{CONCLUSION}

The C1-C6 fragment of the (-)-1 could be prepared from commercial available starting materials using a chemoenzymatic approach. The use of new lipases and DKR (dynamic kinetic resolution) are under investigation by us, as well as the ring closing metathesis key step to the construction of the tenmembered ring of $(-)-\mathbf{1}$.

\section{ACKNOWLEDGEMENTS}

FAPESP, CNPq, CAPES

\section{REFERENCES}

${ }^{1}$ Evidente, A.; Lanzetta, R.; Capasso, R.; Andolfi, A.; Bottalico, A.; Vurro,

M.; Zonno, M. C. Phytochemistry 1995, 40, 1637.

${ }^{2}$ For the first total synthesis of $(-)-1$ see: Sabitha, G.; Swapna, K. Y. R.; Yadav, S. J. Tetrahedron Lett. 2009, 50, 5417.

${ }^{3}$ Vurro, M.; Ellis, B. E. Plant Sci. 1997, 126, 29.

${ }^{4}$ Vilalba, B. T.; Bianco, G.G.; Longo, Jr. L. S. In: 34 ${ }^{a}$ RASBQ; Águas de Lindóia, SP, Brazil. 28-30 May, 2010.

$14^{\text {th }}$ Brazilian Meeting on Organic Synthesis $-14^{\text {th }}$ BMOS - September 01-05, 2011-Brasilia, Brazil 